\title{
When developing countries meet transnational universities: searching for complementarity and dealing with dual embeddedness
}

Article

Accepted Version

Guimón, J. and Narula, R. (2020) When developing countries meet transnational universities: searching for complementarity and dealing with dual embeddedness. Journal of Studies in International Education, 24 (3). pp. 314-336. ISSN 10283153 doi: https://doi.org/10.1177/1028315319835536 Available at https://centaur.reading.ac.uk/82229/

It is advisable to refer to the publisher's version if you intend to cite from the work. See Guidance on citing.

To link to this article DOI: http://dx.doi.org/10.1177/1028315319835536

Publisher: Sage

All outputs in CentAUR are protected by Intellectual Property Rights law, including copyright law. Copyright and IPR is retained by the creators or other copyright holders. Terms and conditions for use of this material are defined in the End User Agreement. 


\section{CentAUR}

Central Archive at the University of Reading

Reading's research outputs online 


\title{
When developing countries meet transnational universities: searching for complementarity and dealing with dual embeddedness
}

\author{
forthcoming, Journal of Studies in International Education
}

\author{
José Guimón (corresponding author) \\ Department of Development Economics \\ Universidad Autónoma de Madrid, Spain \\ jose.guimon@uam.es \\ Tel. +34-615664246 \\ http://orcid.org/0000-0002-7391-7659 \\ https://scholar.google.com/citations?user=yMe9Nr0AAAAJ
}

\section{Rajneesh Narula}

John H. Dunning Centre for International Business, Henley Business School

University of Reading, UK

r.narula@henley.reading.ac.uk

http://orcid.org/0000-0002-4266-2681

https://scholar.google.com/citations?user=3MXaF3kAAAAJ\&hl=en

\begin{abstract}
During the last two decades, a growing number of universities, mainly from developed countries, have established branch campuses in developing countries. From the developing country perspective, attracting foreign universities can help mitigate financial constraints and capacity shortages that impair the state's ability to provide greater access to higher education, while also improving teaching and research in general. However, foreign universities may also be detrimental if they crowd-out their domestic counterparts. We explore different scenarios and policy options for developing countries aiming to attract foreign universities, building upon a review of four case studies from Chile, China, Kazakhstan and Malaysia. Our analysis illustrates how host countries can provide incentives to align incoming foreign universities to complement and strengthen the areas of weakness in their higher education systems. We also reflect on how policy-makers can deal with the challenges associated with the dual embeddedness of international branch campuses.
\end{abstract}

Keywords: transnational university; international branch campus; dual embeddedness; crowding-out 


\section{Introduction}

A growing number of universities, mainly from developed countries, have established international branch campuses (IBC) in developing countries to tap into a larger student base and leverage their global reputation (Wilkins 2016). This trend follows the expansion of global capitalism (Marginson 2017) and has been spurred by the inclusion of higher education as tradable services in recent rounds of international trade negotiations (Altbach 2015). Those critical of the international expansion of universities are concerned about the neoliberal logic of privatization and/or the imposition of western educational models (Sidhu and Christie 2014). Other observers hope that it will foster political and economic relations, facilitating a new era of international relations (Heitor 2015).

From the developing country perspective, attracting foreign universities may contribute to mitigating financial constraints and capacity shortages that impair the state's ability to provide greater access to higher education, while also improving the quality of teaching in general (Agarwal 2015; Schendel and McCowan 2016). In addition to teaching, foreign universities may also become involved in research domestically, leading to the development of science and innovation capabilities in the industrial and commercial sectors (Kolesnikov et al. 2017). However, it is also recognized that these benefits do not accrue automatically, and depending on the circumstances, foreign universities might be detrimental to the enhancement of existing national universities.

The objective of this paper is to examine the policy options for developing countries to attract foreign universities that ramp up their higher education and innovation systems. We contribute to recent research on transnational education, with a particular focus on the implications for host countries rather than on universities themselves as prevalent in existing studies.

\section{Analytical background}

Several developing countries have offered new incentives to attract foreign universities, yet it has only been very recently that studies have analyzed the potential benefits and risks of this kind of policy strategy. Attracting foreign universities may be more cost effective than setting up or expanding national universities, since it transfers part of the cost and organizational burden to experienced foreign actors (Knight 2014). Compared with financing selected students to enroll in universities abroad, the establishment of IBCs to operate in situ may allow more students to obtain a quality education at a lower cost, while mitigating the risk of brain drain (Wilkins 2016).

Beyond education, attracting the research activities of foreign universities can contribute to building a critical mass of research capacities in designated priority areas (Horta and Patrício 2016; Youtie et al. 2017). Moreover, it represents an opportunity to enhance international technology transfer and diffusion; to bolster learning and demonstration effects on local universities; and to increase a country's attractiveness for R\&D-related investments by multinational companies (Klerkx and Guimón 2017; Pfotenhauer et al. 2016).

However, relying on foreign universities does not necessarily assure quality and attention to local needs (Knight 2014). Countries aspiring to leverage the expertise of foreign universities tend to face substantial barriers, tensions and governance challenges, as illustrated with the case of Singapore (Sidhu 2009). Academic credentials, quality education experiences, and related institutional and cultural capital do 
not necessarily travel smoothly across space (Leung and Waters 2013). Rather, such attributes tend to be "sticky" and need to be properly nurtured in new spaces in order to germinate. Moreover, an excessive reliance on foreign universities for the development of a country's higher education system can produce a crowding-out of its national universities.

\subsection{Crowding-out versus complementarity}

The notion of crowding-out has been used extensively in the international business literature to analyze the impact of foreign direct investments (FDI) by multinational enterprises in developing countries (Agosin and Machado 2005; Farla et al. 2016) and is equally relevant for the specific case of transnational universities. National universities may be crowded-out as a result of the arrival of foreign universities if public funding is diverted, they experience a decline in fee-paying students, and face greater difficulties in attracting talented faculty.

A key challenge for host countries is to simultaneously avoid crowding-out while fostering complementarity; a delicate balance that is influenced by host country characteristics and institutions, as discussed by Farla et al. (2016) in relation to FDI. To this end, incentives need to be in place to stimulate the local embeddedness of IBCs, such that they become aligned with domestic interests. However, IBCs have to respond to the sometimes-conflicting demands of their host and their home country academic regulatory authorities. This dual embeddedness may lead to tensions.

\subsection{Dual embeddedness}

The notion of dual embeddedness has been used to refer to the commitment of IBCs with both their home and host countries' institutions and stakeholders (Shams and Huisman 2016). According to Heitor (2015: 282), the fact that IBCs are subject to the demands of their home and host institutional settings creates a "three-lateral contingency" which may cause "system dysfunctions". In a similar vein, Sidhu and Christie (2014: 192) contend that IBCs should be interpreted as "a matrix of different spatial practices that strand together". A recent study of Canadian offshore schools in China (Wang 2017) identifies inconsistencies in policy-making and implementation motivated by the excessive focus of countries on their own interests and values, without paying sufficient attention to the legal, political and cultural features of the partner country. Indeed, for IBCs to achieve legitimacy, they need to conform to the rules and belief systems in the host countries (He and Wilkins 2017).

On a more general level, recent research on higher education policy has stressed that the increasing demands placed on universities along their different missions (teaching, research, innovation, regional development) may exceed universities' capacities to respond, leading to a "mission overload" (Enders and De Boer 2009). This risk of mission overload is even more acute in the case of IBCs given their dual embeddedness.

\subsection{Policy options for host countries}

Different universities may have different motivations to establish an overseas campus and may opt for different entry modes (Guimón 2016). Likewise, nations aiming to attract foreign universities may have different objectives and priorities (e.g. undergraduate or graduate studies, teaching or research, etc.) and 
may rely on many different policy programs and operational approaches. In this paper we draw attention to the following policy options:

- Establishing joint-ventures between foreign and local universities: Under this model, local universities can increase their reputation by linking with a global brand, while enhancing their teaching and research capacities. The expectation is that the local university will learn from the experience and input of a foreign university, while both institutions share risks and rewards (Olds 2007).

- $\quad$ Creating a new public university in partnership with foreign universities: This is similar to the previous model, but the host country retains full ownership of the new university. The government may partner with one or several universities to create a new institution with strong teaching and research capacities. This option implies higher national control over the new venture but also higher costs, given the lack of financial commitment of foreign universities.

- Attracting foreign universities to provide university degrees: In this case, foreign universities are allowed to established fully-owned campuses in the country. Some governments have launched dedicated programs to attract a group of selected foreign universities into a newly developed campus. In addition to providing better education opportunities to national students, the objective of such programs may be to develop a "higher education hub" that attracts foreign students (Knight 2014).

- Attracting foreign universities to create research centers: Rather than the formation of 'generic' human capital through formal education, in this case the primary objective is to develop a critical mass for research that contributes to enhancing the absorptive capacity of local firms, and in some cases to foster a purposeful redirection of domestic research efforts towards designated priority areas (Hird and Pfotenhauer 2017).

\section{Method}

Our research objective was to explore alternative policy programs to attract foreign universities, paying special attention to the measures undertaken under different circumstances to foster complementarity of IBCs with local actors and to deal with the challenges associated with their dual embeddedness. We followed an exploratory and qualitative method, relying on a multiple case study. The cases constitute recent policy programs to attract foreign universities implemented in four middle-income countries (Table 1). As in any case study, our research suffers from sampling bias, which hampers the generalizability of its results. In particular, we acknowledge that the countries covered in our study are not representative of the whole collective of developing countries and could be labeled instead as emerging countries, but we consider that their experience represents an interesting learning model also for countries at earlier stages of development. The countries cover a variety of continents, but the main criteria to select the cases was their capacity to illustrate the different policy options discussed in Section 2.3, rather than geographic representation. Selecting a single policy approach used across several countries would have enabled deeper cross-case comparisons focusing on the influence of socio-political and cultural contexts, but we adopted a "maximum variation" case selection strategy (Flyvbjerg 2006) aimed at providing a more comprehensive mapping of the variety of policy options available. 


\section{-- Table 1 around here --}

To develop the case studies, the first stage in the data collection process involved a review of secondary sources, including scientific publications, policy reports and websites of the different IBCs involved. The second stage consisted in personal interviews with key informants, including high-level policy-makers in charge of running these programs and senior directors of the IBCs (Table 2). These semistructured interviews were conducted in 2014-17 and lasted $1 \mathrm{~h}$ on average.

\section{-- Table 2 around here --}

In order to tease out implications from different policy options and link them with the analytical categories discussed in Section 2, our process of data collection and coding was structured around three themes. First, we summarized each policy program and its motivations. Second, we analyzed further the specific policy design choices taken to foster the complementarity of IBCs with local actors. Third, we looked into how dual embeddedness may hamper the benefits for host countries and the sustainability of IBCs. After analyzing each of the cases in isolation (Section 4), we drew broader implications from crosscase analysis (Section 5).

\section{Individual analysis of the case studies}

\subsection{China: Joint-ventures between foreign and national universities}

China's higher education system was opened up to foreign universities in 2003 through a legislation that allowed the establishment of IBCs in partnership with Chinese institutions. This was intended to provide a cost-effective solution to expand the provision of higher education, while learning from international best practices (Ennew and Fujia 2009).

According to the regulations, a Chinese institution must hold at least a 50 per cent share of the joint venture and the President of the IBCs must be Chinese (Fazackerley 2007). Applications for establishing these joint-ventures are subject to the examination and approval of the Chinese government, upon presenting a detailed report of planned activities, a draft of the cooperation agreement between the foreign university and the local partner, and a financial plan. Around 44 IBCs have been created so far in China as joint-ventures, most of which are US or UK universities ${ }^{1}$. These IBCs offer degrees in the name of the foreign university, and often also joint-degrees - a Chinese and a foreign one. Some are large campuses covering a wide range of disciplines, while others are small units focusing on a specific program. For example, the Chinese campus of the Johns Hopkins University is a small center focusing on international relations, with around 100 Chinese and American students. Particularly noteworthy among the larger interdisciplinary campuses are those of Nottingham and Liverpool universities, with around 6000 and 7000 students respectively, which are the biggest IBCs in the world (Wilkins 2016).

\footnotetext{
${ }^{1}$ Authors' calculations based on C-BERT Branch Campus Listing, available at http://cbert.org/branchcampus/ (Last accessed November 19, 2018)
} 
This model aims to enforce linkages with local actors in order to foster spillovers and enhance complementarities. The following quote from our interview with a Chinese policy-maker illustrates the expected benefits from this approach:

The aim was to make sure that Chinese universities collaborate intensively with foreign universities, in order to learn from their management, teaching and research practices. It is also a way of enhancing the international reputation of the Chinese institutions, since their name appears jointly with the name of the foreign university. I would say that we are in general happy with the results, although there are large differences by institution (...) but the actual learning effects and other impacts are hard to measure.

Although most IBCs in China initially focused on education, in recent times a stronger emphasis on research can be observed. A noteworthy example is the partnership formed in 2010 between the University of Michigan and Peking University to create in China the Joint Institute for Translational and Clinical Research (Youtie et al. 2017). The objective of the Chinese partner was to develop clinical research capacity, which was relatively weak in the country. Meanwhile, Peking University Health Science Center offered a huge number of patients, which made it an attractive testing environment for the University of Michigan Medical School. This illustrates the importance of fostering complementarities between local and foreign institutions.

According to our interview with the director of a European university that has established an IBC in China, "A key challenge when operating in China is that it takes a lot of time and effort to find the right local partner and to establish personal contact with the key local players. Relationship building is critical”. Building such relationships requires a deep understanding of the Chinese system and the ability to formulate "win-win" propositions, adapted not only to the needs of the Chinese university but also to the wider government strategies. As discussed in Slowinski et al. (2018: p. 14): “Chinese universities are closely tied to the government (...) these institutions interact in complex ways, have multiple areas of overlapping interests and support/hinder each other based on factors that are not obvious to the Western observer".

Beyond finding the right local partner and obtaining the necessary government approvals, the subsequent governance of IBCs is facing a wide range of challenges related to their dual embeddedness. These include financial issues (such as the difficulty for foreign universities to repatriate earnings), cultural frictions, management challenges, and unresolved issues regarding degree recognition, accreditation and quality assurance (Ong and Chan 2014; Yang 2008). Another frequent challenge relates to the different views and expectations regarding the hiring of academic staff (Gow 2007). As explained by one of our interviewees:

Most international universities that have created IBCs in China are not making money, there are often frictions and disputes between the Chinese and international partners, and international universities complain that the link with the government is slow and bureaucratic. The outcome of the project is below initial expectations and often they would like to exit, but closure is not easy, 
there are very high sunk costs involved, plus it is difficult to send money out of China. In addition, top management at universities still see it as a strategic investment that will pay off in the future.

On the political front, the traditional commitment to academic freedom and autonomy in western universities that establish a presence in China clashes with the Chinese government's stance to avoid infiltration of western values, as evidenced by inspections to universities undertaken since 2017 by the Communist party's Central Commission for Discipline Inspection (Feng 2017).

\subsection{Kazakhstan: Building a new public university with international partners}

During the last decade, Kazakhstan has undertaken different initiatives to modernize and expand its higher education system (OECD 2016). One of the most ambitious has been the creation of Nazarbayev University in 2010 with an initial investment of US\$ 2 billion. This brand new state-owned university was developed through strategic partnerships with a set of twelve foreign universities that were selected to develop each of the university's schools and departments (Table 3). Partnerships with foreign universities included course licensing agreements, consultation and advice, and services in the form of specified deliverables based on contracts with limited terms. Ownership of the university remained fully in the hands of Kazakhstan's government.

\section{-- Table 3 around here --}

Nazarbayev University was conceived as a pilot project to provide a model for the reform of the old Soviet-style university system, by adhering to higher academic standards, academic freedoms, and a model of shared faculty governance (Schweber 2013). It was granted the status of "autonomous educational institution", and thereby the freedom to create its own governing structures and curricula. A former vicepresident of the World Bank, of Japanese origin, was hired as President of the University. The university's Board of Trustees is formed of government officers $(50 \%)$ and representatives of the university's international partners $(50 \%)$.

The university focusses on disciplines closely aligned with the country's industrial needs and the perceived shortcomings in the higher education system, including engineering, science and technology, mining, medicine, business and education (OECD 2016b). All teaching is in English and 85\% of faculty are foreign. According to our interviews, one of the challenges that the university is facing relates to retaining international professors from the partner institutions, who normally are not willing to relocate permanently in Kazakhstan nor to spend prolonged periods of time in Kazakhstan.

Although initially focused only on teaching, in recent years a stronger effort is being placed on enhancing the university's research activity also with support of foreign actors. A new science park called the Astana Business Campus was created in 2015 within Nazarbayev University with the advice of the High Tech Business Campus Eindhoven, a Dutch science park. As explained in the following quote from our interview with the university's President:

We are a very young university and our priority up to now has been to consolidate our teaching programs, but we are now also making strong efforts on research. We aim to become an attraction 
pole for multinational companies and we also want to inspire a cultural change in the country, introducing new models of university-industry collaboration and public-private partnerships.

In addition to the newly established research laboratories affiliated with the different schools of Nazarbayev University, a variety foreign multinationals and local companies have also located innovation centers in the Astana Business Campus. Notably, the Samruk-Kazyna sovereign wealth fund, Kazakhstan's largest corporation that groups together most state-owned enterprises, has established its main corporate research center on campus. The International Scientific and Technological Centre has also relocated from Moscow to the Astana Business Campus. A set of supporting organizations have been created within the Campus, including a commercialization office, a research support office, and a business incubator. Despite these efforts, there is little evidence of substantial increase in research outputs or collaboration.

Nazarbayev University complements the country's university sector, by focusing on certain academic disciplines and providing high quality teaching programs in English, while fostering demonstration and learning effects on local universities. However, some of our interviewees expressed concerns over the crowding-out of other national universities. The development of Nazarbayev University has displaced public investments in other national universities and has also brought along challenges for national universities to recruit (and retain) the best professors and students. In the words of one of our interviewees:

\footnotetext{
Huge sums of public money have been invested in this project. In some ways it is an excellent idea and it is having an important impact in the country (...) But I think it would have been better to use that money to improve already existing universities, perhaps with a focus on those that appear higher in international rankings, rather than creating a brand new institution (...) increased funding for research, together with a program to support international partnerships by already established universities, could have been more efficient.
}

Another concern with this model of international partnerships is that the local embeddedness of foreign universities is limited, given that they have not established a legal entity in the country nor participate as shareholders of Nazarbayev University. Their future commitment will thus depend on continued funding provided by the government for the provision of specific services.

\subsection{Malaysia: Developing a higher education hub}

Malaysia's agenda for establishing itself as an education hub through the attraction of foreign universities was a response to two interrelated motivations (Morshidi et al. 2011). First, to develop the human capital base needed to shift from its current economic model based on natural resources and lowcost manufacturing, towards a knowledge-based economic development model. Second, to exploit the opportunities of higher education as an export sector in light of growing demand for higher education services across the region.

The entry of foreign universities into Malaysia was first regulated by the Private Higher Education Institutions Act of 1996, which enabled the establishment of IBCs in the country subject to approval by the 
Ministry of Higher Education (Mok 2011). In 2007, the National Higher Education Strategic Plan 2020 further advanced the government's plan to transform the country into a higher education hub through the attraction of foreign universities.

In this context, several IBCs have been established around Kuala Lumpur and in the Southern province of Johor, close to the border with Singapore. We will focus here on the latter, where a special project called EduCity was developed to attract foreign universities within 205 acres of state-owned land located at the Iskandar special economic zone (Shams and Huisman 2016). EduCity offers incentives to selected international universities including access to buildings to host the IBCs, as well as shared student accommodation, conference centers, and sports facilities. So far, the Malaysian government, in coordination with the regional government of Johor, has concluded agreements with seven foreign universities to create IBCs (Table 4). The first was Newcastle University, in November 2011, which offers medical degrees recognized by the British Medical Council.

\section{-- Table 4 around here --}

These IBCs specialize in different disciplines, including business, digital media, ICT, engineering, medicine and pharmacy, among others. This disciplinary focus forms part of a policy approach aimed at developing the necessary skills for a knowledge-based economy, while addressing current areas of weakness in the national higher education system. All IBCs established in EduCity offer qualifications in the name of a foreign university, and some of the programs envision the possibility for students to spend a term or a year abroad in the home country of the university.

A key challenge of this model is that IBCs are subject to a double accreditation process: from the Malaysian Ministry of Higher Education and from their home country academic authorities. This dual embeddedness leads to higher administrative hassles and institutional conflicts (Dobos 2011; Mok 2011; Shams and Huisman 2016). As illustrated in the following quote from a vice-chancellor of one of the international universities located in EduCity, initial expectations were not always fulfilled:

The local environment was presented to us as very favorable, but we found that the real environment in the ground was not as favorable as expected. First, the accreditation process for our degrees was much longer than what Malaysian authorities had promised, and this led to a delay in the recruitment of students. Second, the government introduced very stringent visa requirements for international students, which is also an important obstacle to student recruitment. This contradicts the country's strategy of becoming a higher education hub. Third, the shared facilities of EduCity, such as student accommodation and sport facilities, which were an attractive incentive for us to locate there, are failing to meet the standards that we expected.

Another challenge relates to the possible crowding-out of local universities in the market for academic staff, since the best-qualified Malaysian academics often prefer to work for incoming international universities than for local universities. While the Malaysian government is aware of this risk and tries to dissuade overseas universities from hiring too many national academics, incoming universities want to shift progressively towards local staff who do not need to receive expatriate compensation levels. 
(Whitehead 2012). At the same time, immigration rules make it hard to attract quality foreign academics. According to our interview with the CEO of one of the IBCs established in EduCity:

The Ministry of Higher Education gives IBCs a target of 30\% of academic staff being from the parent university (which is not met by any campus, so far as I am aware); however, immigration rules mean we cannot offer work to a foreign national which could be done by a Malaysian, and since work permits are only issued for two-year periods we are not allowed to offer anything longer than a 2-year fixed term contract of employment. Understandably, not all international academic staff find that a tempting prospect.

Beyond education activities, the Malaysian government also expects that the development of EduCity will serve to stimulate R\&D cooperation with firms, within the context of the broader development of an economic corridor in Iskandar. This is consistent with the second phase of Malaysia's National Higher Education Strategy, launched in 2011 with the objective of transforming the country not only into an education hub to attract international students, but also into a technology and innovation hub (Aziz and Abdullah 2014). Creating such linkages also depends crucially on a stable and highly skilled contingent of world-class academics.

\subsection{Chile: Creating research centers with foreign institutions}

The International Centers of Excellence program in Chile was launched in 2009 to create new research centers by foreign universities and public research institutes. The program aimed at strengthening the technological capabilities of Chilean industries and at triggering a systemic change in the national innovation system by promoting science-industry collaboration (Klerkx and Guimón 2017).

Through the two calls for proposals issued so far (2009 and 2011), a total of eight universities and public research institutes from seven different countries have established R\&D centers in the country (Table 5). Each center received a grant of up to US\$ 20 million for a 10-year period, covering up to $40 \%$ of the center's total budget. The program focused on a set of strategic industries and technologies including traditional industries (i.e. food processing and mining), emerging industries (i.e. renewable energy) and general purpose technologies with applications across different industries (i.e. ICT, biotechnology and nanotechnology).

\section{-- Table 5 around here -.}

The centers were selected based on their capacity to establish linkages with local firms and universities. On the industry side, the centers were expected to develop and transfer new technological solutions to increase the competitiveness of Chilean industries through joint research projects, contract research and technology commercialization. On the university side, the centers were required to hire Chilean scientists and to establish collaboration agreements with Chilean universities. They were also expected to contribute to the training of young scientists by hosting and co-supervising $\mathrm{PhD}$ students and postdocs and by participating in postgraduate programs ran by Chilean universities. According to one of the policy-makers that we interviewed: 
Our aim was to bring into the country foreign research institutions with demonstrated experience in linking with industry and commercializing technology, so that they would produce a shaking effect to address a key gap that we had identified in the national innovation system. The centers were expected to foster linkages and joint projects with Chilean universities and companies, leading to more relevant, multidisciplinary and applied research.

The first and largest center established in Chile under this program is an affiliate of Fraunhofer, the German public research institute. The Fraunhofer Chile center currently employs over 140 researchers and has signed more than 50 contracts with industry in its first years of operation. According to one of our interviewees:

Fraunhofer has demonstrated a strong commitment to expanding its activities in Chile, and has provided more funding than originally expected, as it is perceived that the Chilean center will contribute substantially to the overall ambitions of Fraunhofer of becoming a global research institute. Chile offers a unique environment for some of the research carried out at Fraunhofer, for example in the area of agriculture and mining technologies.

The Chilean International Centers of Excellence program illustrates how the creation of applied research centers in partnership with foreign institutions can contribute to the development of science and innovation capacities in emerging countries, while also providing an opportunity for world class universities and public research institutes to expand their international scope, to perform research in settings they lack in their home countries, and to access new streams of funding. Ultimately, a successful implementation of this type of program requires careful attention to the differing strategic interests between host country and foreign institutions. However, a number of challenges may be emerging in relation to the dual embeddedness of these centers, as illustrated by the following quotes from our interviews:

Once the center got started, we had to spend a lot of time and effort negotiating contracts with our partner institutions, in particular with regard to the ownership of intellectual property rights and the distribution of licensing royalties. We needed to align expectations and we experienced unexpected conflicts with some of our partner universities.

Building a relationship of trust with Chilean firms is harder than what we thought initially. Chilean firms normally search for ready-to-use technology and are reluctant to finance the development of new technologies [and] assuming a risk. They are not used either to participate in research consortia with other firms. There are cultural barriers such as lack of trust and low propensity to collaborate when it comes to engaging with firms.

The monitoring processes are very rigid and inefficient. We are subject to an administrative slavery. Every single expense is audited with a very precarious IT system which is very costly for 
us (...) at the same time, we also need to continue reporting back to our home institution and to comply with all our internal procedures.

The main challenge expressed by the five executive directors of the International Centers of Excellence that we interviewed is the difficulty of earning income from contract research with local firms, which will become increasingly important to ensure the long-term sustainability of the centers after they stop receiving baseline funding from the Chilean government. A condition for the centers' longer term sustainability is to demonstrate not only that the centers are having an impact locally, but that they provide benefits for the parent organization and its home country that could justify future funding. In other words, the sustainability of the International Centers of Excellence requires a proper balancing of Chilean interests and the interest of the organization in their home countries (see also Klerkx and Guimón 2017).

\section{Cross-case analysis}

The case studies analyzed illustrate the variety of policy options available for developing countries to attract foreign universities and organizations, including different kinds of regulations, co-financing schemes, and targeted subsidies. In particular, the case studies serve to capture different scenarios with respect to the focus on teaching or research, the extent of local ownership in the newly created universities, and the mechanisms used to enhance complementarity and linkages (Table 6). The case studies also highlight the key challenges associated with balancing the interests of both parties. We now discuss, for each of these dimensions, the key conclusions that emerge from cross-case analysis.

\section{-Figure 1 around here -}

\section{Table 6 around here}

First, regarding the extent of local ownership, the case of Nazarbayev University in Kazakhstan provides the maximum degree of local ownership, since it is fully owned by the national government, although foreign universities have created each of the university's departments and occupy 50 per cent of the seats in the university's Board of Trustees. The degree of local ownership is also high in China, since IBCs need to partner with a Chinese institution that holds at least a 50 per cent share of the joint-venture.

Second, with respect to the focus on teaching or research, Chile is the most extreme case, since it aimed at attracting applied research centers from the outset. The other cases focused initially almost exclusively on teaching, but have progressively expanded their scope towards research, with different degrees of intensity. Such reorientation in the missions of IBCs throughout their history has also been observed in other case studies that emphasize the importance of engaging in locally-led partnerships rather than just transplanting successful programs from the home university (Schmid et al. 2018).

Third, these case studies highlight the various challenges that have emerged in the implementation of such international higher education partnerships, which are broadly associated with counteracting local regulations, differences in objectives of host country and home university of the IBCs, and other kinds of cross-country communication problems and strategic misalignments. This suggests that the strategic and institutional idiosyncrasies of the different parties involved require careful cross-cultural communication 
to be grounded in negotiations and sense-making efforts. In the absence of such efforts, initial partnership agreements may lead to expectations that cannot be met during implementation. Administrative hassles and institutional conflicts derived from working in a cross-cultural setting are certain to arise, and there should be mechanisms to address these jointly. Therefore, it is essential to clearly define the rights and responsibilities of both the host government and the IBCs through contracts or memoranda of understanding, while also permitting the foreign partner space to renegotiate agreements as they become familiar with the host country environment. Indeed, these policy schemes should aim to balance more explicitly the benefits for the host country with those of the parent unit at the home country. For IBCs to remain sustainable in the middle to long term, they need to demonstrate not only local impact, but also benefits for the foreign partner.

Fourth, all the case studies showed signs of policy efforts to align incoming foreign organizations with identified problems in their countries' higher education and innovation systems. The different policy programs departed somewhat from their intended objectives, but each aimed at complementing their national higher education and innovation systems by addressing some of their shortcomings. This involved, for example, targeting specific disciplines where national universities lacked capacities, as in the case of Malaysia. In Chile, the aim was to improve the national innovation system by attracting foreign universities and public research institutes with a proven capacity of performing applied research in collaboration with industry. In Kazakhstan, given the rigid education system inherited from the Soviet era, the government decided to create a new university in partnership with foreign institutions that could instigate a demonstration and learning effect on local universities. For China, the rationale for attracting foreign universities was to keep up with the high growth of demand for higher education as well as to foster internationalization at a time when the country was opening up to the world.

Cross-case analysis is also useful to underline the importance of nurturing linkages between foreign institutions and local actors in order for complementarities and spillovers to unfold, while illustrating different policy approaches to achieve this. For example, in China, foreign universities were only authorized to operate through joint ventures with local institutions, with the aim of fostering learning and reputational effects. In Kazakhstan, foreign universities collaborated in the development of a brand new university of national origin, transferring knowledge and human resources. In Chile, the capacity of incoming institutions to establish collaboration agreements with local universities and to work with local firms were among the main criteria in the selection and evaluation process of the International Centers of Excellence program. In the case of Malaysia's EduCity, the attraction of foreign universities was connected to a regional development plan to develop a higher education hub and an economic corridor.

Our research does not permit us to measure the relative impacts of the different policy approaches, or the extent to which the policy objectives behind each model are actually being met. More rigorous research would be necessary to clarify these points, although the information required to do so is very hard to obtain, since many of the expected impacts are intangible in nature.

\section{Conclusions}

The most appropriate policy approach to attract foreign universities depends on a country's specific characteristics, its institutional context, and available resources, in addition to the influence of 
different interest groups. Perhaps most significantly, countries need to be explicit about their desired outcomes, and to be aware that there are important trade-offs in pursuing multiple goals simultaneously. For example, attracting a university to establish a research-intensive campus in a remote, rural location achieves three policy outcomes (regional development, human capital upgrading, and research capacity) in principle, but in practice, such a campus is unlikely to attract and retain high-quality faculty or students. Policies to attract foreign universities must be associated with the provision of appropriate complementary assets. Locating a foreign branch campus requires investment in high quality infrastructure. Basic inputs such as transportation links, reliable electricity and water are essential, but so are facilities for staff and students.

The relationship between foreign universities and governments is often complicated by fundamental differences in their objectives. The foreign organisation, as with most economic entities, desires to maximise the returns for its stakeholders however they define these returns. Unless there are specific political agreements between the university/institute's home country and the host government relating to the branch campus, the foreign partner measures the outcome much like any multinational corporation, and these interests are primarily economic and/or strategic. On the other hand, the host government seeks to maximise the return for their stakeholders, which may relate to social welfare, equality and political objectives. Although not a zero-sum game, the fact is that both sides must explicitly appreciate that each has different objectives, and finding common ground requires acknowledging that all parties may have to compromise on their expectations.

Building a higher education sector through foreign branch campuses requires considerable resources, not only in terms of locational infrastructure, but also in terms of regulation. If developing countries encourage the entry of foreign branch campuses, but lack the regulatory capacity to ensure the quality of education being offered, then the quality of graduates will tend to remain low. Regulation requires monitoring and enforcement of contractually agreed standards, and this necessarily requires penalties for missed targets and sub-standard performance, alongside incentives. Effective monitoring requires regulatory authorities to have the appropriate organizational resources, and these are often lacking in developing countries.

Lastly, not everyone can afford to offer strong financial inducements to attract the 'right quality' of international branch campuses. Smaller countries may not represent significant markets, and need to offer greater financial incentives to overcome the limited revenues from student fees. Not all developing countries have the financial resources to duplicate the policy programs discussed in our case studies.

Despite its potential benefits, the attraction of foreign universities does not guarantee quality and attention to local needs, and the risk of crowding-out national universities persists. As with any policy analysis, the decision to allocate public resources to (often costly) programs to attract foreign universities should be judged against its opportunity cost. It is evident that if the government provides funding to foreign universities, less public funding will be available for national universities and research institutes. Thus, sound arguments based on a realistic assessment of expected benefits are necessary to justify public funding of incoming foreign universities rather than expanding the capacity of national universities. For this purpose, this paper has suggested that it is critical for public policies to provide incentives that align the activities of foreign universities with local needs, fostering complementarity and links with local 
universities, governments and firms, while recognizing more explicitly the challenges associated with the dual embeddedness of international branch campuses.

\section{References}

Agarwal, P. (2015). Next two decades of higher education: a developing countries perspective, International Higher Education, 80: 3-4.

Agosin, M.R. and Machado, R. (2005). Foreign investment in developing countries: does it crowd in domestic investment? Oxford Development Studies, 33: 149-162.

Altbach, P. (2015). Knowledge and education as international commodities. International Higher Education, 28: 2-5.

Aziz, M.I.A. and Abdullah, D. (2014). Malaysia: Becoming an education hub to serve national development. In: Knight, J. (Ed.) International Education Hubs: Student, Talent, Knowledge-Innovation Models, Springer, London.

Dobos, K. (2011). "Serving two masters" - academics' perspectives on working at an offshore campus in Malaysia, Educational Review, 63: 19-35.

Enders, J. and De Boer, H. (2009). The mission impossible of the European university: Institutional confusion and institutional diversity. In: Amaral, A. et al. (Eds.) European integration and the governance of higher education and research, Springer Netherlands.

Ennew, C.T. and Fujia, Y. (2009). Foreign universities in China: a case study. European Journal of Education, 44: 21-36.

Farla, K., de Crombrugghe, D. and Verspagen, B. (2016). Institutions, foreign direct investment, and domestic investment: crowding out or crowding in? World Development, 88: 1-9.

Feng, E. (2017). Ideological purge hits China universities with western ties. Financial Times, April 15, 2017.

Flyvbjerg, B. (2006). Five misunderstandings about case-study research. Qualitative Inquiry, 12: 219245.

Gow, I. (2007). Removing the rose-tinted spectacles, In: Fazackerley, A. (Eds.) British universities in China: the reality beyond the rhetoric. Agora Discussion Paper.

Guimón, J. (2016). Universities as multinational enterprises? The multinational university analyzed through the eclectic paradigm. Multinational Business Review, 24: 216-228.

He, L. and Wilkins, S. (2017). Achieving legitimacy in cross-border higher education: institutional influences on Chinese international branch campuses in South East Asia. Journal of Studies in International Education, First Published November 1, 2017.

Heitor, M. (2015). How far university global partnerships may facilitate a new era of international affairs and foster political and economic relations? Technological Forecasting \& Social Change, 95: 276-293.

Hird, M.D. and Pfotenhauer, S.M. (2017). How complex international partnerships shape domestic research clusters: Difference-in-difference network formation and research re-orientation in the MIT Portugal Program. Research Policy, 46: 557-572.

Horta, H. and Patrício, M.T. (2016). Setting-up an international science partnership program: A case study between Portuguese and US research universities. Technological Forecasting \& Social Change, 113: $230-239$. 
Klerkx, L. and Guimón, J. (2017). Attracting foreign R\&D through international centres of excellence: early experiences from Chile. Science and Public Policy, 44: 763-774.

Knight, J. (2014). International education hubs: student, talent, knowledge-innovation models, Springer, London.

Kolesnikov, S., Woo, S., Li, Y., Shapira, P. and Youtie, J. (2017). Mapping the emergence of international university research ventures. The Journal of Technology Transfer, First Online: 17 November 2017.

Leung, M.W.H. and Waters, J. (2013). British degrees made in Hong Kong: an enquiry into the role of space and place in transnational education, Asia Pacific Educational Review, 14: 43-53.

Marginson, S. (2017). The World-Class Multiversity: Global commonalities and national characteristics. Frontiers of Education in China, 12: 233-260.

Mok, K.H. (2011). The quest for regional hub of education: growing heterarchies, organizational hybridization, and new governance in Singapore and Malaysia. Journal of Education Policy, 26: 61-81.

Morshidi, S., Razak, A.A. and Koo, Y.L. (2011). Trade in services and its policy implications: the case of cross-border/transnational higher education in Malaysia, Journal of Studies in International Education 15: $241-60$.

OECD (2016). Reviews of National Policies for Education: Higher Education in Kazakhstan, OECD Publishing, Paris.

Olds, K. (2007). Global Assemblage: Singapore, Foreign Universities, and the Construction of a Global Education Hub, World Development, 35: 959-975.

Ong, K.C. and Chan, D.K.K. (2014). Transnational higher education and challenges for university governance in China, in: Mok, K.H., \& Yu, K.M. (Eds.) Internationalization of higher education in East Asia. New York: Routledge.

Pfotenhauer, S.H., Wood, D., Roos, D. and Newman, D. (2016). Architecting complex international science, technology and innovation partnerships (CISTIPs): A study of four global MIT collaborations. Technological Forecasting \& Social Change, 104: 38-56.

Schendel, R. and McCowan, T. (2016). Expanding higher education systems in low-and middle-income countries: the challenges of equity and quality. Higher Education, 72: 407-411.

Schmid, J., Kolesnikov, S. A. and Youtie, J. (2018). Plans versus experiences in transitioning transnational education into research and economic development: a case study. Science and Public Policy, 45: 103-116.

Schweber, H. (2013). Innocents abroad? The University of Wisconsin in Kazakhstan. The Huffington Post, September 6, 2013.

Shams, F. and Huisman, J. (2016). The role of institutional dual embeddedness in the strategic local adaptation of international branch campuses: evidence from Malaysia and Singapore. Studies in Higher Education, 41: 955-970.

Sidhu, R. (2009) Running to stay still in the knowledge economy, Journal of Education Policy, 24: 237 253.

Sidhu, R. and Christie, P. (2014). Making space for an international branch campus: Monash University Malaysia. Asia Pacific Viewpoint, 55: 182-195.

Slowinski, G., Johnson, A., Hummel, E. and Story, B. (2018). Building University Relationships in China. Research-Technology Management, 61: 51-54. 
Wang, F. (2017). Canadian offshore schools in China: a comparative policy analysis, Journal of Education Policy, 32: 523-541

Whitehead, F. (2012). Inside Educity Iskandar: a university partnership in Malaysia. The Guardian, 8 May 2012.

Wilkins, S. (2016). Transnational higher education in the 21st Century. Journal of Studies in International Education 20: 3-7.

Yang, R. (2008). Transnational higher education in China: Contexts, characteristics and concerns. Australian Journal of Education, 52: 272-286.

Youtie, J., Li, Y., Rogers, J. and Shapira, P. (2017). Institutionalization of international university research ventures. Research Policy, 46: 1692-1705. 
Table 1. Overview of the case studies

\begin{tabular}{|l|c|c|l|}
\hline \multicolumn{1}{|c|}{ Program } & Country & Launch date & \multicolumn{1}{c|}{ Policy approach } \\
\hline International joint-ventures & China & 2004 & $\begin{array}{l}\text { Creating regulations and incentives to induce foreign } \\
\text { entry through joint ventures with local universities. }\end{array}$ \\
\hline Nazarbayev University & Kazakhstan & 2010 & $\begin{array}{l}\text { Building a world-class university with international } \\
\text { partners. }\end{array}$ \\
\hline Educity & Malaysia & 2010 & $\begin{array}{l}\text { Developing a higher education hub through the attraction } \\
\text { of several foreign universities to a new campus. }\end{array}$ \\
\hline $\begin{array}{l}\text { International Centers of } \\
\text { Excellence Program }\end{array}$ & Chile & 2009 & $\begin{array}{l}\text { Attracting applied research centers of foreign universities } \\
\text { and public research institutes. }\end{array}$ \\
\hline
\end{tabular}

Source: Authors. 
Table 2. Interviews

\begin{tabular}{|c|c|c|}
\hline Case study & $\begin{array}{l}\text { Number of } \\
\text { interviews }\end{array}$ & Type of interviewees \\
\hline China & 3 & $\begin{array}{l}\text { - Director of an international branch campus in China } \\
\text { - Vice-Chancellor of a university with a branch campus in China } \\
\text { - Chinese policy officer working on issues related to innovation and higher education }\end{array}$ \\
\hline Kazakhstan & 7 & $\begin{array}{l}\text { - President, Nazarbayev University } \\
\text { - Deputy Vice-Rector, Nazarbayev University } \\
\text { - } \text { Deputy Chairman, Ministry of Education and Science } \\
\text { - } \text { Director, Ministry of Industry Investments and Development } \\
\text { - }\end{array}$ \\
\hline Malaysia & 3 & $\begin{array}{l}\text { - CEO of an international branch campus in EduCity } \\
\text { - Pro-Vice-Chancellor for Global Engagement of a university with a branch campus in } \\
\text { EduCity } \\
\text { - Director of Department of a university with a branch campus in EduCity }\end{array}$ \\
\hline Chile & 9 & $\begin{array}{l}\text { - Directors (5) of international universities and public research institutes established in Chile } \\
\text { - Top executives (3) of national innovation agency } \\
\text { - Director of Innovation Division at Ministry of Economy }\end{array}$ \\
\hline Total & 22 & \\
\hline
\end{tabular}

Source: Authors. 
Table 3. International partners of Nazarbayev University, Kazakhstan (2010-2016)

\begin{tabular}{|c|c|c|}
\hline Name of university & Country of origin & Nazarbayev's School / Department \\
\hline University of Chicago & USA & National Laboratory Astana (Energy and Life Sciences) \\
\hline Colorado School of Mines & USA & School of Mining \\
\hline Duke University & USA & Graduate School of Business \\
\hline University of California Berkeley & USA & National Laboratory Astana (Energy and Life Sciences) \\
\hline National University of Singapore & Singapore & Graduate School of Public Policy \\
\hline Oak Ridge Associated Universities & USA & Nazarbayev University Research and Innovation System \\
\hline University College London & UK & School of Engineering \\
\hline University of Cambridge & UK & Graduate School of Education \\
\hline University of Pennsylvania & USA & Graduate School of Education \\
\hline University of Pittsburgh & USA & School of Medicine \\
\hline University of Warwick & UK & Nazarbayev University Foundation Year Program \\
\hline University Wisconsin-Madison & USA & School of Humanities and Social Sciences \\
\hline
\end{tabular}

Source: Nazarbayev University (http://nu.edu.kz/) 
Table 4. International branch campuses established in EduCity, Malaysia (2010-2016)

\begin{tabular}{|c|c|c|c|c|}
\hline $\begin{array}{l}\text { Management and Development } \\
\text { Institute of Singapore }\end{array}$ & Singapore & 2013 & 2000 & $\begin{array}{l}\text { Business, Tourism \& Hospitality, Mass } \\
\text { Communication, Information } \\
\text { Technology, and Digital Media. }\end{array}$ \\
\hline $\begin{array}{l}\text { Multimedia University - University of } \\
\text { Southern California }\end{array}$ & USA & 2014 & 500 & Cinematic arts \\
\hline $\begin{array}{l}\text { Netherlands Maritime Institute of } \\
\text { Technology }\end{array}$ & Netherlands & 2010 & 1600 & $\begin{array}{l}\text { Transport, shipping, seafaring, maritime } \\
\text { and logistics management }\end{array}$ \\
\hline Raffles University & India & 2012 & 5000 & $\begin{array}{l}\text { Design \& Art, Business, Education \& } \\
\text { Social Sciences, ICT }\end{array}$ \\
\hline University of Reading & UK & 2015 & 2000 & $\begin{array}{l}\text { Real estate, construction, finance, law, } \\
\text { chemistry and pharmacy }\end{array}$ \\
\hline University of Southampton & UK & 2012 & 1100 & $\begin{array}{l}\text { Electrical, mechanical and aerospace } \\
\text { engineering }\end{array}$ \\
\hline
\end{tabular}

Notes: Number of students refers to estimation for 2016-2019 provided in EduCity website.

Source: EduCity (https://www.iskandarinvestment.com/master-planned-development-projects/educity/) and universities' websites. 
Table 5. Universities and public research institutes established in Chile under the International Centers of Excellence Program (2010-2016)

\begin{tabular}{|c|c|c|c|}
\hline Institution & $\begin{array}{l}\text { Country of } \\
\text { origin }\end{array}$ & $\begin{array}{l}\text { Year } \\
\text { created }\end{array}$ & Main research lines \\
\hline DCNS & France & 2015 & Marine renewable energy, including tidal power and wave power. \\
\hline Fraunhofer & Germany & $\begin{array}{l}2011 \& \\
2015\end{array}$ & $\begin{array}{l}\text { Biotechnology applied to raw materials, agriculture, aquaculture and the } \\
\text { sustainable use of natural resources. Solar energy technologies. Cities of the } \\
\text { future. }\end{array}$ \\
\hline Inria & France & 2012 & $\begin{array}{l}\text { Digital technologies, computer science, and mathematics, with applications } \\
\text { across different sectors including aquaculture, mining, astronomy, solar } \\
\text { energy, recycling, e-government, etc. }\end{array}$ \\
\hline $\begin{array}{l}\text { University of } \\
\text { California Davis }\end{array}$ & United States & 2014 & $\begin{array}{l}\text { Agriculture, genetic improvement, adaptation to climate change, post-harvest } \\
\text { waste treatment, viticulture and enology. }\end{array}$ \\
\hline $\begin{array}{l}\text { University of } \\
\text { Queensland }\end{array}$ & Australia & 2016 & $\begin{array}{l}\text { Sustainable mining, mineral processing, mining and geology, water } \\
\text { management. }\end{array}$ \\
\hline $\begin{array}{l}\text { Wageningen } \\
\text { University }\end{array}$ & Netherlands & 2013 & Food processing, food safety, agriculture, sustainability. \\
\hline
\end{tabular}

Source: Adapted from Klerkx and Guimón, 2017. 
Table 6. Comparing policy approaches: cross-case analysis

\begin{tabular}{|c|c|c|c|c|c|}
\hline Case study & $\begin{array}{l}\text { Focus on } \\
\text { education }\end{array}$ & $\begin{array}{l}\text { Focus on } \\
\text { research }\end{array}$ & $\begin{array}{l}\text { National } \\
\text { ownership }\end{array}$ & Dual embeddedness and other challenges & Enhancing complementarity and linkages \\
\hline China & High & Medium & Medium & $\begin{array}{l}\text { - Difficulty for foreign institutions to repatriate } \\
\text { earnings } \\
\text { - Unresolved issues regarding degree recognition, } \\
\text { accreditation and quality assurance. } \\
\text { - Different expectations regarding the hiring of } \\
\text { academic staff from the foreign institution. } \\
\text { - Difficulty for foreign institutions to find the } \\
\text { right local partner and negotiate an agreement } \\
\text { - Chinese government interference in academic } \\
\text { affairs damages academic autonomy of IBCs }\end{array}$ & $\begin{array}{l}\text { - IBCs need to be established as joint ventures } \\
\text { between foreign and local partners, providing } \\
\text { learning opportunities and reputational benefits } \\
\text { - Chinese partner must hold }>50 \% \text { of joint venture and } \\
\text { President of IBC must be Chinese } \\
\text { - Applications for establishing IBCs are subject to } \\
\text { approval of Chinese government, upon examining } \\
\text { report of planned activities, draft of the cooperation } \\
\text { agreement between the partners, and a financial plan. } \\
\text { - Although still focused on education, increasing } \\
\text { emphasis on research to meet local industry demands }\end{array}$ \\
\hline Kazakhstan & High & $\begin{array}{l}\text { Medium- } \\
\text { Low }\end{array}$ & High & $\begin{array}{l}\text { - Development of Nazarbayev University has } \\
\text { displaced public investments in other national } \\
\text { universities } \\
\text { - Challenges for other national universities to } \\
\text { recruit the best professors and students } \\
\text { - Lack of interest of academics from parent } \\
\text { university to relocate in Kazakhstan. } \\
\text { - Retention and sustainability of partnerships with } \\
\text { foreign universities depends on continued public } \\
\text { funding, because foreign universities have not } \\
\text { established a legal entity in the country nor } \\
\text { participate as shareholders the university }\end{array}$ & $\begin{array}{l}\text { - Partnerships with foreign universities based on } \\
\text { contracts that regulate course licensing agreements, } \\
\text { consultation and advice, and other services. } \\
\text { - The university's Board of Trustees is formed of } \\
\text { government officers }(50 \%) \text { and representatives of the } \\
\text { university's international partners }(50 \%) \text {. } \\
\text { - Focus on disciplines aligned with the country's needs } \\
\text { and shortcomings in higher education system } \\
\text { - Nazarbayev University aims to instigate earning } \\
\text { effects on local universities } \\
\text { - Although still focused on education, a new science } \\
\text { park was created to engage in more research activity. }\end{array}$ \\
\hline Malaysia & High & Low & Low & $\begin{array}{l}\text { - Double accreditation process of IBCs (from } \\
\text { Malaysia and country of origin) leads to } \\
\text { administrative hassles and institutional conflict } \\
\text { - IBCs attract highly qualified Malaysian } \\
\text { academics, at the expense of local universities. } \\
\text { - Malaysian authorities establish that IBCs should } \\
\text { bring }>30 \% \text { of academic staff from the parent } \\
\text { university but it is very hard to meet this target }\end{array}$ & $\begin{array}{l}\text { - Foreign universities need approval from Ministry of } \\
\text { Higher Education before establishing an IBC. } \\
\text { - IBCs target prioritize disciplines where national } \\
\text { universities lack capacities } \\
\text { - IBCs offer students to spend a term/year in the home } \\
\text { country of the university } \\
\text { - EduCity forms part of a regional development plan } \\
\text { to build a higher education hub and an economic } \\
\text { corridor }\end{array}$ \\
\hline Chile & Low & High & Low & $\begin{array}{l}\text { - Local firms lack absorptive capacity to benefit } \\
\text { from research conducted by foreign labs } \\
\text { - Difficult to assess benefits for the university of } \\
\text { origin and its home country that could justify } \\
\text { future funding from country of origin. } \\
\text { - Concerns over sustainability after foreign labs } \\
\text { stop receiving baseline funding from Chilean } \\
\text { government } \\
\text { - Research centers need to comply with } \\
\text { inefficient, bureaucratic monitoring processes } \\
\text { from Chilean government }\end{array}$ & $\begin{array}{l}\text { - The capacity of international institutions to } \\
\text { collaborate with local universities and firms is a key } \\
\text { criteria in the selection and evaluation process } \\
\text { - Focus on strengthening the country's technological } \\
\text { capabilities in a set of strategic industries and } \\
\text { technologies }\end{array}$ \\
\hline
\end{tabular}

Source: Authors. 